\title{
The Effect of Training and Ability on the Performance of Employee at Disaster Management Bureau of Central Kalimantan Province
}

\author{
Yunikewaty \\ Department of Management, Faculty of Economic and Science Management, \\ Study Program of Science Magister, State University of Palangkaraya \\ Corresponding Author
}

Doi:10.5901/mjss.2017.v8n3p87

\begin{abstract}
This study aims to examine and determine the effect of training and ability on the performance of employee at Disaster Management Bureau of Central Kalimantan Province. The results of this study are expected to contribute to the discourse of science in the field of human resource management. This is an explanatory research which explains the relationship between exogenous variables and endogenous variables. It took 34 employees as the sample by implementing saturated sampling as the method. The data were analyzed with Structural Equation Modeling (SEM) using PLS software. The results showed training and ability have direct and positive effect on the performance of employee at Disaster Management Bureau of Central Kalimantan Province.
\end{abstract}

Keywords: training, ability, performance, disaster management bureau, Structural Equation Modeling (SEM)

\section{Introduction}

As the main institution dealing with disaster management in the region that performs coordination functions, carries out command, and becomes the implementer, the quality improvement of human resources is one of the foremost keys in the efforts of disaster management. Human resources play as both subject and object in order to be able to act in their capacity in managing disaster matters.

Factors which mostly have hampered the performance at Disaster Management Bureau are low skills, lack of capability of human resource in disaster management, and limited infrastructure to support the disaster management. Therefore, standards of competence need to be improved so that knowledge on disaster management can be known accurately and comprehensively.

Disaster Management Bureau of Central Kalimantan Province needs human resources that meet the standards of competence at the conceptual, managerial, or technical level in the field of disaster management. Therefore, training in disaster management is indispensable to improve the quality of human resources. Additionally, staffing process based on educational background and ability of employees is highly required.

According Simamora (2010:342) training is a systematic process of changing the behavior of the employees in a direction to improve organizational goals. On the other hand, McKenna and Nic Bech (2008: 198) explained that training is the concept of planned training which is a careful intervention designed to generate the necessary understanding to improve work performance. The study conducted by Otuko et al. (2013) also showed that training is fundamentally important and highly influences the performance of employees.

Farlin cited in Winardi (2005:92) argued competency-based human resources require continuous grow and powerful ability to respond the challenges of globalization. Human resources within an organization must have the competence needed by the organization for the survival and development of the organization. For that reason, the implementation of the management of human resource recruitment should be oriented on the competency model.

In line with the above notion, Zhijian et al. (cited in Islamy, 2001:13) strengthened that the development of a 
company that puts customers as asset that must be preserved and maintained is, therefore, determined by the level of mobility (performance) and ability of the people who work in the company. Khan et al. (2014) described that training has strong and positive effect on the performance of employee. This was confirmed by research conducted by Sunarto (2012) explaining that training has a significant effect on the performance of employee.

The improvement of disaster management ability of Human Resources at Disaster Management Bureau of Central Kalimantan Province is intended to establish a reliable apparatus that can carry out their duties effectively and efficiently and can compete within the development and advancement of era. If the employees demonstrate skillful ability, they will be able to easily perform disaster management which becomes the objective of the organization. As proposed by Faustino (2010:145), ability is the extent to which employees have the knowledge, skills, interpersonal abilities as well as the technical abilities, and the power to generate performance.

A research carried out by Aisha, Hardjomidjojo, and Yassierli (2013) showed that the ability to work significantly influences employee's performance. Siahaan (2013) also explained that the ability to work has a direct effect on the performance of employee.

Performance is a measure that shows employee's attitude in performing the duties and functions of the organization. Based on Presidential Decree No. 10 of 2005 on the organizational unit since its establishment in 1974, one of the main purposes of research and development activities at the Agricultural Research and Development Bureau in the next five years (2005- 2009) is Improving the capacity and professionalism and moral integrity of human resources, quality and availability of facilities/infrastructure, and innovative work and business oriented culture.

Based on the above explanation, ability is the significant aspect of an employee, especially the employees at Disaster Management Bureau of Central Kalimantan Province. In this institution, the ability of the employee in some aspects has a very important role to deal with disaster relief. After recognizing each employee's ability, staffing process in the unit is conducted.

Every organization wants employees who have skilful ability and high motivation to achieve the objectives of organization. The performance of employees at Disaster Management Bureau of Central Kalimantan Province is the accumulation of each individual performance. Therefore, the performance of each employee is an important factor that needs to be paid a serious attention. In order to make the performance of each employee continuously improve, factors such as training, ability, and staffing process must be taken seriously.

To produce the performance of employees which meets the expectations of the Bureau, it should be supported by a powerful ability to contribute positively to the performance. In fact, the performance of the Bureau's employees, as reflected in the results of disaster management implementation, has not been optimal.

This occurrence is caused by weak ability and low enthusiasm of the employees. In terms of ability, the weakness of some employees is due to the inexpediency of level of education, skills, and knowledge of the employee with the field work.

Disaster Management Bureau of Central Kalimantan Province is a newly formed institution. Therefore, it is deemed necessary to do research on the factors influencing employee's performance. In this matter, training and ability are seen as the most appropriate variables to be analyzed in influencing employee's performance.

\section{Research Methods}

This research is an explanatory research which describes the relationship between variables through hypothesis testing. The sample in this study is 34 employees of Disaster Management Bureau of Central Kalimantan Province. The sampling technique implemented saturated or census sampling by taking the whole population as sample.

\subsection{Data Collection}

The data were obtained from questionnaires, in which several written questions related to the variables examined were given to the employees at Disaster Management Bureau of Central Kalimantan Province. Besides, the data were also gained from the archives of the number of employees, an overview of the Regional Disaster Management Bureau of Central Kalimantan Province, job descriptions, and organizational structure.

\subsection{Data Analysis}

The data analysis employed Structural Equation Modeling (SEM) using PLS software. 


\section{Results and Discussion}

Hypothesis testing on the research was carried out based on significance values obtained in each lane in the research model. Significance values are considered eligible for the relation between significant variables when the $p$-value below $0.05(p<0.05)$.

The test using the analysis of Structural Equation Modeling (SEM) was conducted to obtain the results of analysis of the relationship among independent variables, mediator variables and dependent variable that occurred directly or indirectly. The results of analysis were then used to test the hypothesis proposed in the study. The recapitulation of the analysis using Structural Equation Model testing is presented in Table 1.

Table 1. The Result of Hypothesis Testing

\begin{tabular}{|c|c|c|c|c|c|c|}
\hline Exogenous Variable & $\begin{array}{c}\text { Original } \\
\text { Sample }\end{array}$ & $\begin{array}{c}\text { Mean } \\
\text { Sample }\end{array}$ & $\begin{array}{c}\text { Standard } \\
\text { Deviation }\end{array}$ & $\begin{array}{c}\text { Standard } \\
\text { Error }\end{array}$ & T Statistics & Description \\
\hline Ability (Y1) -> Employee's Performance (Y3) & 0.200499 & 0.198758 & 0.071371 & 0.071371 & 2.809263 & Significant \\
\hline training (X) -> Employee's Performance (Y3) & 0.707377 & 0.711176 & 0.043874 & 0.043874 & 16.122994 & Significant \\
\hline
\end{tabular}

Source: Data compiled from PLS output, 2015

The result of analysis as presented in Table 1 shows coefficient value acquisition of direct effect of training on the performance of employee is at 0.7073 with $T_{\text {statistics }}>T_{\text {Table }}(16.1229>1.96)$, meaning that there is a significant effect of training on employee's performance. It indicates that the hypothesis "training gives positive effect on the performance of employees at Disaster Management Bureau of Central Kalimantan Province" is accepted. The results of this analysis showed the presence of training can improve the performance of employee at Disaster Management Bureau of Central Kalimantan Province.

Hypothesis testing on the effect of ability on performance showed coefficient values of direct effect of ability on employee's performance is at 0.20049 with $T_{\text {statistics }}>T_{\text {Table }}(2.809>1.96)$, meaning that there is a significant effect of ability on employee's performance. It indicates that the hypothesis "training gives positive effect on the performance of Disaster Management Bureau employee of Central Kalimantan Province" is accepted. The results of analysis showed the presence of training can improve the performance of Disaster Management Bureau employee of Central Kalimantan Province.

\section{Discussion}

\subsection{Effect of Training on Employee's Performance}

The analysis showed that training has significant effect on the performance of employees at Disaster Management Bureau of Central Kalimantan Province. The parameter coefficient 0.707 means there is a direct effect of training on the performance of employees. It indicates that training is capable of contributing to the improvement of performance of employees at Disaster Management Bureau of Central Kalimantan Province. The better and more targeted the training is delivered to the employee, the more their performance improve.

The result of the study is supported by previous study conducted by Winda et al. (2014: 10). Based on the results of hypothesis testing with $t$ test, it was found that the training variable brings positive and significant effect on the performance of the employees at the Inspectorate Office of Manado, meaning that training is very important in improving the performance of employees at the Inspectorate Office of Manado. The results of the study explained that the training followed by the employees at the Inspectorate Office of Manado can assist them in carrying out the duties and functions. In other word, training can improve the employee's performance. The quality of the employees who attend training is influenced by several factors, such as type, management, and material of the training as well as the evaluation of the training implementation. This is in line with the respondents of the study most of whom put their perception on the training they have been followed in good category. The results are in line with the research conducted by Turere (2013) showing that training variable significantly influence employee's performance.

The results of the study are supported by Simamora (2010: 346) stating that the main purpose of training is to improve performance. Training for civil servants can be also called as training and education program (DIKLAT) aimed to create a common vision and dynamics of mindset in carrying out public administration duties and development for the realization of good governance. Through training, civil servants can perform a more skilful ability to work. It can be said a 
better training program given to the employees at Disaster Management Bureau of Central Kalimantan Province will bring them into better performance.

\subsection{Effect of Ability on Employee's Performance}

The analysis showed that ability give effect to the employee's performance. The coefficient 0.2004 means that there is an effect of ability on the performance of employees at Disaster Management Bureau of Central Kalimantan Province. It shows that the higher the ability of the employees is, the higher its effect on their performance. In other word, ability can contribute to the quality of employee's performance. The results of this study are supported by research conducted by Andree (2010: 13) showing that ability is influenced by cognitive, social, emotional, cultural intelligence and physical abilities. It implies that employees with high intelligence and supported by good physical condition will effortlessly perform their duties so that it would be easy to achieve the expected performance. In conclusion, if the employee's ability is increasing, their performance will accordingly increase. The results of the analysis show that the effect of ability on the employee's performance is significantly positive, meaning that if ability variable is increased, employee's performance will also increase.

\subsection{Implications of Research Results}

The results showed that training and ability directly influence employee's performance. Therefore, Disaster Management Bureau of Central Kalimantan Province needs to involve its employees in the trainings organized by the Centre of Disaster Management Bureau. Additionally, Disaster Management Bureau of Central Kalimantan Province has to build harmony in the organization to achieve good cooperation between employees and employers and among employees. Employees also need to be given the opportunity to improve their competence. Sometimes, the Bureau should give challenging targeted jobs so as to provide sufficient pressure for employees to develop their expertise. The improvement of competence can be carried out in the form of training, courses, seminars, and coaching. In addition to in-door education, employees might also be invited to learn outdoors, for example outbound and games to strengthen the cohesiveness of the teamwork. Other activities that support learning and togetherness can be a joint sport and socialspiritual events in the office. Institution, through management, can provide an environment that reinforces the principles of community, namely the harmonious, intimate, and mutual relationship supporting one another.

\section{Conclusion}

The results showed that training and ability directly influences the performance of employees at Disaster Management Bureau of Central Kalimantan Province. The results of path analysis also showed the coefficient value of direct effect of training on employee's performance is at 0.7073 with $\mathrm{T}_{\text {statistics }}>\mathrm{T}_{\mathrm{Table}}(16.1229>1.96)$ while the coefficient of direct effect of ability on employee's performance is 0.20049 with $\mathrm{T}_{\text {statisics }}>\mathrm{T}_{\text {Table }}(2809>1.96)$.

\section{References}

Andree,W. S.(2010). The effect of ability and motivation on employee's performance. Journal ekonomi Sekolah Tinggi Ekonomi Widiya Manggala, 2010, 2(3):1-17.

Aisha, A. N., Hardjomidjojo, P, and Yassierli. (2013). The effects of working ability, working condition, motivation and incentive on employee's multi-dimensional performance. International Journal of Innovation, Management and Technology, Vol. 4, No. 6.

Faustino, G. E. (2010). Manajemen Sumber Daya Manusia. Yogyakarta: Andi Offset.

McKenna, E and Beech, N. (2008). The Essence of Human Resource Management. translated by Tatok Budi Santoso. Yogyakarta: Andi Offset.

Otuko, A. H,. Gabriel, K., Douglas, M. (2013). Effect of training dimensions on employee's work performance: a case of mumias sugar company in Kakamega County. International Journal of Business and Management Invention, 2(9), 138-149. Retrieved from www.ijbmi.org

Siahaan, B. Z. (2013). Effect of work ability, role perception and motivation work to performance employees administration Jakarta State University. Journal of Management Education

Simamora, H. (2010). Human Resource Management. Yogyakarta: The Publishing STIE. YKPN.

Turere, N. V. (2013). Influence and training of increasing employee performance at the technical training center of the faculty of economics. Journal of Agricultural Economics, University of Sam Ratulangi, 1 (3), 10-19.

Winda, J. R; peggy a. Mekel I.O. (2014). Education, training and job placement influence on the performance of employees in Manado city inspectorate office. Journal of Economic, Sam Ratulangi University of Manado, 2(2), 1284-1295.

Winardi. (2011). Leadership in Management. Jakarta: Rineka Cipta.

Zhang, Z., Gizman, R. P. D. (1992). Administrative reform towards promoting productivity in bureacratic performance, Eropa Secretariat General, Manila, Philippines. 